\title{
Delta Variant of Covid-19 Study, and Why it is a Concern: An Overview
}

\author{
Majid Monajjemi ${ }^{1, * \mathbb{C}}$, Fatma Kandemirli ${ }^{2 \mathbb{D}}$, Fatemeh Mollaamin ${ }^{2(\mathbb{D})}$ \\ 1 Department of Chemical engineering, Central Tehran Branch, Islamic Azad University, Tehran, Iran \\ 2 Department of Biomedical Engineering, Faculty of Engineering and Architecture, Kastamonu University, Kastamonu, \\ Turkey \\ * Correspondence: m_monajjemi@ srbiau.ac.ir (M.M.); maj.monajjemi@iauctb.ac.ir (M.M.);
}

Scopus Author ID 670181068

Received: 27.08.2021; Revised: 3.10.2021; Accepted: 6.10.2021; Published: 24.10.2021

\begin{abstract}
COVID-19 is caused by the virus SARS-CoV-2 that belongs to the Coronaviridae groups. The subgroups of the coronavirus families are $\alpha, \beta, \gamma$, and $\delta$ coronavirus (the four general human coronaviruses). Representative coronaviruses consist of NL63 coronavirus (human) and porcine transmissible gastroenteritis from the Alphacoronavirus genus; mouse hepatitis coronavirus (MHV), bovine coronavirus (BCoV), severe acute respiratory syndrome coronavirus (SARS-CoV), and Middle East respiratory syndrome coronavirus (MERS-CoV); avian infectious bronchitis virus (IBV); and porcine $\delta$-coronavirus $(\mathrm{PdCoV})$. This work exhibits, $\delta$-coronavirus spikes are fundamentally and evolutionally more similar related to $\alpha$-coronavirus spikes than to $\beta$-coronavirus or $\gamma$-coronavirus spikes due to the receptor recognition, membrane fusion phenomenon, and immune evasion behavior.
\end{abstract}

Keywords: COVID-19; delta coronavirus; spike proteins.

(C) 2021 by the authors. This article is an open-access article distributed under the terms and conditions of the Creative Commons Attribution (CC BY) license (https://creativecommons.org/licenses/by/4.0/).

\section{Introduction}

\section{1. $\delta$-coronavirus pandemic.}

Multiple and mixed SARS-CoV-2 variants are circulating globally in all areas and countries. One of these is the B.1.617 lineage (Delta variant) that was firstly detected in India by starting 2020 year. The evidence and scientific prediction suggest that the Delta variant is much more transmissible than current lineages. The World Health Organization (WHO) categorized all variants as associated with transmissibility increasing or detrimental changes in Covid-19 epidemiology, virulence increasing, decreased effectiveness of public health measures or available diagnostics, vaccines, therapeutics, etc., and some other major factors (Scheme 1).

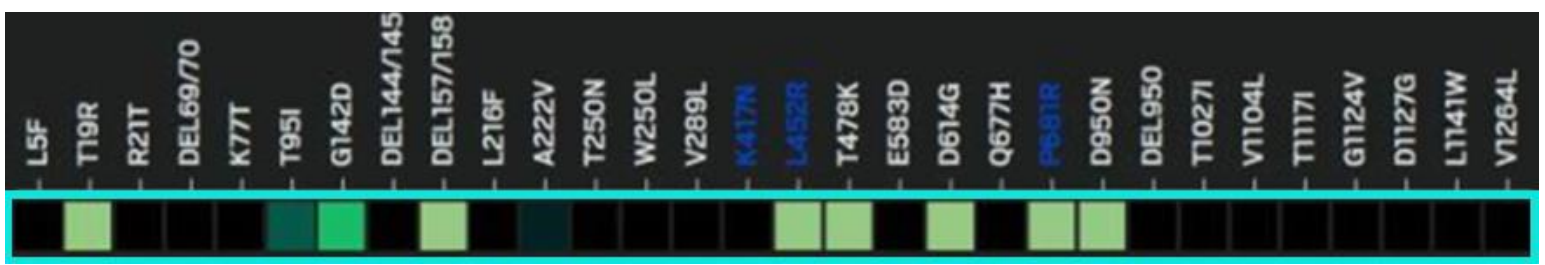

Scheme 1. Classifies the mutations that make a variant.

Different variants are identified through their mutations in the virus's gene. An alteration in each of these RNA bases (that made of about 35,000 base pairs) makes a mutation, 
consequently changing the shape and properties of the virus function. The Delta variant consists of several mutations in the spike protein, where four of them are most important [110]. One of these is known as L452R, which was reported in March 2020 in Denmark firstly. This mutation has been shown to be more transmissible compared with wild-type strains and has also been related to reduced antibody influence and decreased neutralization during vaccination. The P681R's mutation has been related to chemical processes that might enhance transmissibility [3,4]. The D614G mutation first appeared in the US early in the pandemic. There is affirmation with a report of the Centers for Disease Prevention and Control (CDC), those variants with the above-mentioned mutations spread more quickly compared with other variants of COVID-19. T478K is a delta mutation that appeared in around $60 \%$ of occurrences in variant B.1.1.222, was first detected in Mexico City and was included with high infectivity [10-18]. Public Health England stated that Delta exhibits much more growth rating than Alpha through several statistical and experimental analyses. Recently the UK found that $62 \%$ of pandemic cases are delta [5, 6-8]. Consequently, by decreasing the alpha pandemic, Delta cases are rising day by day $[11,12]$. Some variants of mutations that have been associated with changes in their receptors, antibodies generated against the previous infection, and reduced efficacy of treatments are listed in table 1.

Table 1. Specific genetic markers are predicted to affect the transmission, diagnostics, therapeutics, or immune

\begin{tabular}{|c|c|c|c|c|}
\hline Mutated & Variants Name & Spike Protein Substitutions & WHO Label & First Identified \\
\hline B.1.427 & $20 \mathrm{C} / \mathrm{S}: 452 \mathrm{R}$ & L452R, D614G & Epsilon & United States-(California) \\
\hline B.1.429 & 20C/S:452R & S13I, W152C, L452R, D614G & Epsilon & United States-(California) \\
\hline B.1.525 & 20A/S:484K & $\begin{array}{l}\text { A67V, 69del, 70del, 144del, E484K, D614G, } \\
\text { Q677H, F888L }\end{array}$ & Eta & $\begin{array}{l}\text { United Kingdom/Nigeria - } \\
\text { December } 2020\end{array}$ \\
\hline B.1.526 & 20C/S:484K & $\begin{array}{l}\text { L5F, D80G , T95I, Y144, F157S, D253G, } \\
\text { L452R, S477N, E484K, D614G, A701V, } \\
\text { T859N, D950H, Q957R }\end{array}$ & Iota & $\begin{array}{l}\text { United States (New York) } \\
\text { - November } 2020\end{array}$ \\
\hline B.1.617.1 & $20 \mathrm{~A} / \mathrm{S}: 154 \mathrm{~K}$ & $\begin{array}{l}\text { T95I, G142D, E154K, L452R, E484Q, D614G, } \\
\text { P681R, Q1071H }\end{array}$ & Kappa & India - December 2020 \\
\hline B.1.617.3 & $20 \mathrm{~A}$ & $\begin{array}{l}\text { T19R, G142D, L452R, E484Q, D614G, } \\
\text { P681R, D950N }\end{array}$ & & India - October 2020 \\
\hline P.2 & $20 \mathrm{~J}$ & E484K, F565L, D614G, V1176F & Zeta & Brazil - April 2020 \\
\hline
\end{tabular}

Table 2. Characteristics of SARS-CoV-2 Variants of Concern.

\begin{tabular}{l|l|l|l|l} 
Mutated & $\begin{array}{l}\text { Variants } \\
\text { Name }\end{array}$ & Spike Protein Substitutions & $\begin{array}{l}\text { WHO } \\
\text { Label }\end{array}$ & First Identified \\
\hline B.1.1.7 & 20I/501Y.V1 & $\begin{array}{l}\text { 69del, 70del, 144del, E484K, S494P, } \\
\text { N501Y, A570D, D614G, P681H, T716I, } \\
\text { S982A, D1118H, K1191N }\end{array}$ & Alpha & United Kingdom \\
\hline B.1.351 & 20H/501.V2 & $\begin{array}{l}\text { D80A, D215G, 241del, 242del, 243del, } \\
\text { K417N, E484K, N501Y, D614G, A701V }\end{array}$ & Beta & South Africa) \\
\hline B.1.617.2 & 20A/S:478K & $\begin{array}{l}\text { T19R, G142D, 156del, 157del, R158G, } \\
\text { L452R, T478K, D614G, P681R, D950N } \\
\text { D614G, Q677H, F888L }\end{array}$ & Delta & India \\
& & &
\end{tabular}

In addition, a variant of concern is pandemic which there is evidence of an increase in transmissibility, more severe disease, significant reduction in neutralization by antibodies generated during previous infection or vaccination, reduced effectiveness of treatments or vaccines, or diagnostic detection failures that are listed in Table 2. Variants of concern might require one or more appropriate public health actions, such as notification to WHO under the International Health Regulations, reporting to CDC, local or regional efforts to control spread, increased testing, or research to determine the effectiveness of vaccines and treatments against 
the variant [13-15]. Based on the characteristics of the variant, additional considerations may include developing new diagnostics or modifying vaccines or treatments. Current variants of concern in the United States that are being closely monitored and characterized by federal agencies are included in the table below.

Delta has continued to spread globally, including in the UK, India, and Mexico City, with a proportion of cases resulting in more severe disease and hospitalization. Here we estimate the effectiveness of the BNT162b2 and ChAdOx1 vaccines against Delta as compared to Alpha. There were 14,000 symptomatic cases with Delta included in the analysis, 170 of whom were hospitalized. Overall hazard ratios for hospitalization among cases with Delta in vaccinated patients compared to unvaccinated individuals were 0.36 after one dose and 0.28 after two doses $[16,17] . \delta$-coronavirus genomes are the smallest known coronavirus genomes (25,500-26,900 bases), similar to that of another coronavirus: ORF1ab, spike, envelope, membrane, and nucleon-capsid [1-4]. Both $5^{\prime}$ and $3^{\prime}$ ends contain short un-translated regions. The replicas ORF1ab encodes several proteins, including nsp3, nsp5, nsp12, and nsp13, and some proteins with unknown functions [6,9]. However, reverse transcription analyses show that PD-CoVs were present in the US swine as early as August 2013. In addition, a study in Asia and the Middle East indicated a high prevalence and frequent interspecies transmission of avian D-CoVs in healthy aquatic birds.

\subsection{Pig $\delta$-coronavirus.}

PDCoV is recently recognized as enter-pathogenic coronavirus, which causes disease in younger pigs. This disease is usually manifested through diarrhea and fast dehydration with weight loss and can lead to death in negative neonatal piglets [10-15]. PDCoVs were first confirmed in the US, which coincided with the emergence of PEDV [11,14]. The PDCoV HKU15-OH1987 strain first identified in the US has a 98\% nucleotide identity to the prototype Chinese strains PDCoV HKU15-44 and HKU 15-155. Recent serological information indicated the presence of swine PDCoV IgG antibodies as early as 2011. The fact that the diversity of PDCoV in US swine is restricted ( $\geq 99.8 \%$ nucleotide identity) is also contained with the virus. While the exact route of the emergence of PDCoV in the US is unknown, Asia is considered the area of PDCoV origin, where no associations of this pathogen with large clinical diseases were reported. The latter might confirm that PDCoV can be circulating in pigs in that geographical region for some time, inducing partial immunity. In agreement with this theory, some studies have confirmed PDCoV presence in diarrheic pigs in mainland China. Approximately low prevalence and decreased pathogenicity of PDCoV vs. PEDV/transmissible gastroenteritis virus might indicate that PDCoVs have emerged in swine and are incompletely adapted to these host species, resulting in decreased replication and spread and pathogenicity in pigs. Although the analysis data suggested that PDCoV (HKU15) and $\mathrm{SpCoV}$ (HKU17) have contributed to the last ancestor, this information does not account for recombination events, and an evolutionary route contains other intermediate hosts.

\section{3. $\delta$-coronavirus inter transmission.}

The host specificity of CoVs is based on bat/avian species that provide a wide variety of cells and receptors for the different CoVs. In addition, their flocking potentials and abilities for flying long distances can play a role in the generation of new $\mathrm{CoV}$ variants and their dissemination. As avian DCoVs were suggested to have more stringent host species than GCoVs and however, emerging evidence provides several items of the ability of DCoVs, 
including (a) evidence of the circulation of "novel" avian DCoVs in a broad range of host species; (b) emergence of FalCoV UAE-HKU27, HouCoV UAEHKU28, via restructuring between WECoV HKU16 and MRCoV HKU18; (c) emergence of QuaCoV UAE-HKU30 via restructuring among PDCoV HKU15/SpCoV HKU17 and MunCoV HKU13; (d) Emergence of PDCoV HKU15 from restructuring between SpCoV HKU17 and BuCoV HKU11. Moreover, while PDCoV infection was associated with diarrhea chicks and turkey poults, gnotobiotic calves infected with PDCoV-OH had fecal viral RNA shedding and seroconversion but did not develop lesions or disease.

\section{Materials and Methods}

\subsection{Structural analyzing.}

Porcine delta-coronavirus $(\mathrm{PdCoV})$ has been analyzed due to the divergence of their envelope-anchored spike protein. This protein pushes the viral into host cells via first binding to host receptors by the S1 domain and, consequently, fusing host and viral membranes via the S2 subunit. Understanding the structure of spike proteins is critical for knowing cell entry and evolution of immunogenicity peptidase in covid-19 disease. S1 subunits from spikes consist of two subunits, first $\mathrm{N}$-terminal and second $\mathrm{C}$-terminal. Based on the virus, either one or both S1 domains can function as the receptor-binding domain (RBD) via binding to host receptors (Figure 1\&2).

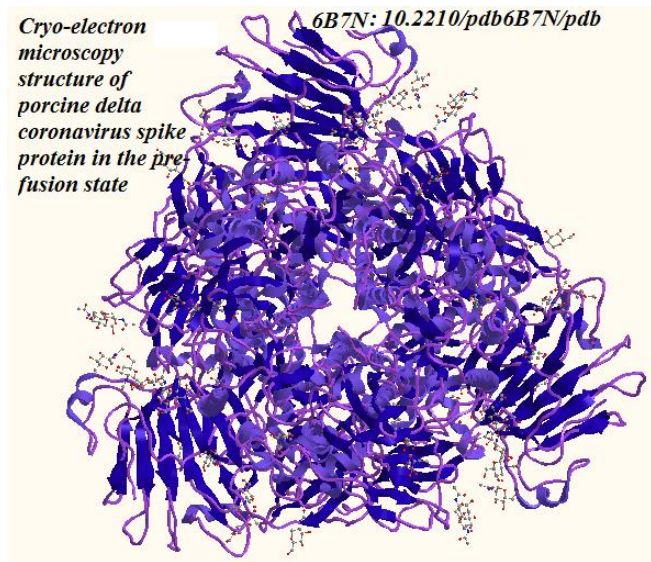

Figure 1. Structure of porcine delta coronavirus spike protein.

On the other side, the S1 domain from coronaviruses has different tertiary structures, but they share a structural configuration, indicating a general evolutionary and divergent evolution of S1-CTDs. Coronavirus S1-CTDs recognize either angiotensin-converting enzyme 2 or amino peptidase-N as their protein receptor, whereas -coronavirus S1-CTDs recognize ACE2 or dipeptide 4. Hence, it has been predicted that coronavirus S1-NTDs originated from host gelatins and have undergone divergent evolution to recognize different receptors. The membrane fusion mechanism for coronavirus spikes is believed to be similar to those used by class 1 viral membrane fusion proteins.

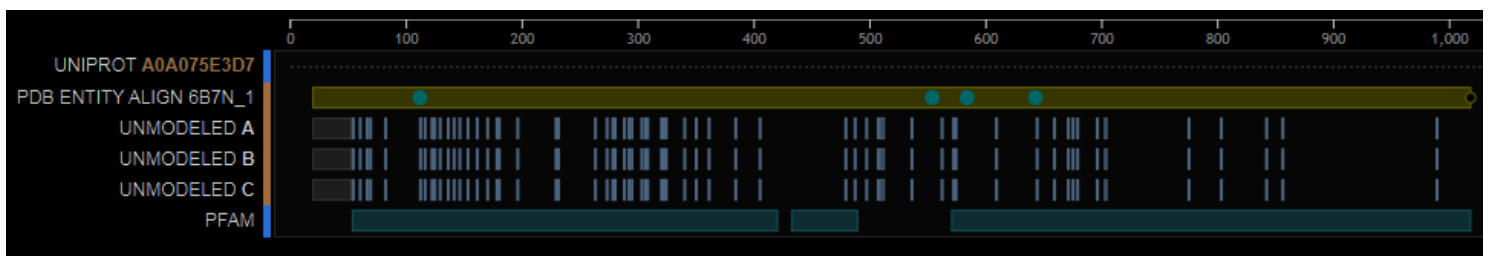

Figure 2. Proteins for A0A075E3D7 (Delta coronavirus PDCoV/USA/Ohio137/2014). 
During the phosphor lipid fusion process, HA1 dissociates, and HA2 undergoes a deep conformational change to reach its postfusion conformation: two heptad repeat (HR) regions from each HA2 subunit, HR-N, and HR-C, refold into a six-helix bundle, and a previously buried hydrophobic fusion peptide (FP) becomes exposed and inserts into host membrane. The cryo-electron microscopy (cryo-EM) structures spike proteins in the perfusion conformation have recently been determined. The overall architecture of - and -coronavirus spikes is similar to, albeit more complex than, influenza HA. Biochemical studies have identified parts of S2 that form six-helix bundle structures and likely correspond to HR-N and HR-C and another part of S2 that associates with membranes and likely corresponds to FP. It was demonstrated that -coronavirus spikes are heavily glycosylated, with S2 being more heavily glycosylated than S1, as a viral strategy for immune evasion. These studies on membrane fusion by - and coronavirus spikes have suggested a common molecular mechanism for membrane fusion shared by coronavirus spikes and other class 1 viral membrane fusion proteins (figure 3 ).

(A)

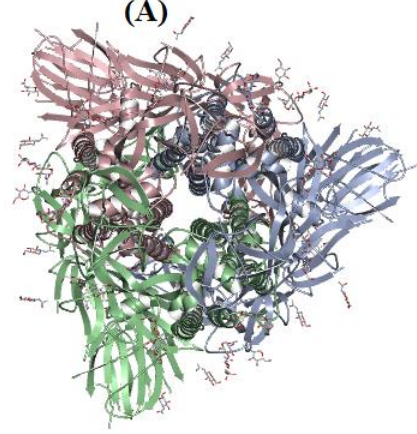

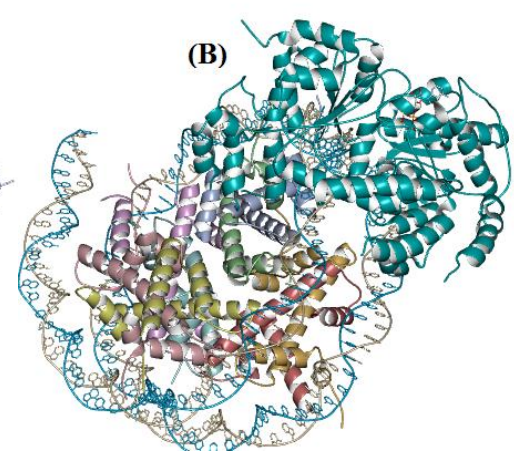

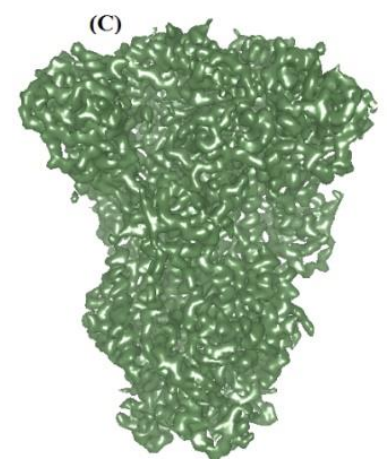

Figure 3. (A) Perfusion SARS-CoV-2 S codomain trimmer covalently stabilized in the closed conformation; (B) Structure of Snf2-nucleosome complex at shl2 in ADP BeFx state; (C) Cryo-electron microscopy structure of porcine delta coronavirus spike protein in the pre-fusion state.

\subsection{Docking and free energy calculations.}

BIOVIA-2020.DS2020Client software has been used for docking calculation, and a grid of $19 \AA$ was produced over the co-crystallized peptide-like inhibitors. Re-docking of the cocrystallized molecules was done for evaluating the docking project. The docked tool was based on a crystal system for calculating. The re-docking of structures and compounds has been built with $1.30 \AA$ and $0.80 \AA$ RMSD, respectively. RMSD in lower amounts indicates a perfect docking and suitable methodology where can be applied to search for small molecule inhibitors. Docking was done in three different modes, virtual screening followed by standardprecision (SP) and extra-precision (XP) docking using the Glide program.

\subsection{M.D. simulations.}

Molecular dynamics modeling for polypeptide-ligand complexes were accomplished using the Desmond software. The OPLS and charm force fields were applied for modeling the interactions of the protein-small molecules. Electrostatic forces were estimated using the Particle-mesh Ewald (PME) software with a grid spacing of $0.85 \AA$ A. Nose-Hoover thermometry and Martyna-Tobias-Klein method were applied for maintaining the temperature and constant pressure, respectively. The motion formula was considered using the multi-run RESPA by 4.0 fs time step for bonded and non-bonded interactions within a low cutoff. 


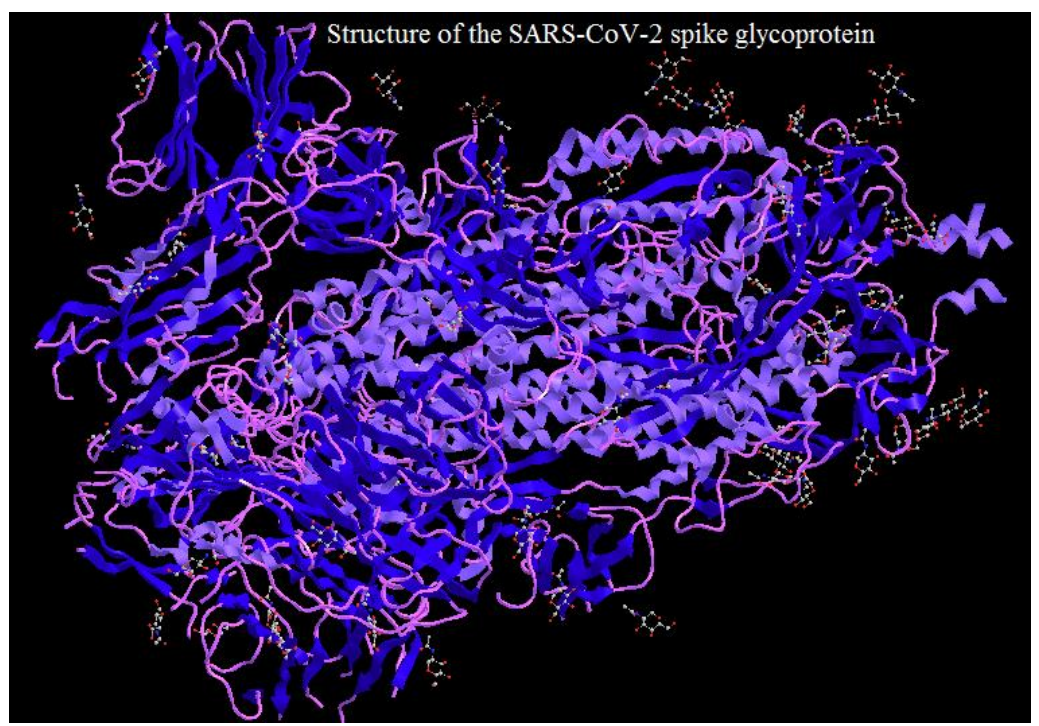

Figure 4. Structure, Function, and Antigenicity of the SARS-CoV-2 Spike Glycoprotein: drawn by chem office software.

\section{Results and Discussion}

\subsection{Simulations for interactions between the CoV2-RBD and the ACE2.}

It can be discussed about the polar and charged residues for many of the fraction and binding interfaces of CoV2-RBD and the ACE2. Moreover, electrostatic interaction has critical points for a complex formation. Distances among the two mentioned proteins are a key at the binding interfaces identified for the three representative models (Figure $5 \&$ Table 3). The majority of those residues are preserved for models. The same simulations can be accomplished for the SARS-RBD/ACE2 complexes.

Table 3. Anti-body and Nucleocapsid antibody of human-derived anti-SARS-CoV-2 S protein RBD

\begin{tabular}{|c|c|c|c|c|}
\hline \multicolumn{5}{|c|}{ neutralizing. } \\
\hline Molecule & Cat. No. & Species & Host & Product Description \\
\hline \multirow{11}{*}{$\mathrm{S} 1$ protein } & $\mathrm{S} 1 \mathrm{~N}-\mathrm{C} 52 \mathrm{H} 3$ & SARS-CoV-2 & HEK293 & SARS-CoV-2, S1-protein \\
\hline & S1N-S52H5 & SARS & HEK293 & SARS-S1-protein, MALS verified (Tag) \\
\hline & $\mathrm{S} 1 \mathrm{~N}-\mathrm{C} 52 \mathrm{H} 4$ & SARS-CoV-2 & HEK293 & SARS-CoV-2-S1 protein, MALS verified (Tag) \\
\hline & S1N-C5255 & SARS-CoV-2 & HEK293 & SARS-CoV-2 (COVID-19) S1 protein, Fc (Tag) \\
\hline & S1N-C5257 & SARS-CoV-2 & HEK293 & SARS-CoV-2 (COVID-19) S1 protein, Fc (Tag) \\
\hline & SPD-S52H6 & SARS & HEK293 & SARS S protein RBD, MALS verified (Tag) \\
\hline & SPD-C5259 & SARS-CoV-2 & HEK293 & SARS-CoV-2 (COVID-19) S protein RBD, Fc (Tag) \\
\hline & SPD-S52H5 & SARS-CoV-2 & HEK293 & SARS-CoV-2 (COVID-19) S protein RBD (N354D), His (Tag) \\
\hline & SPD-S52H7 & SARS-CoV-2 & HEK293 & SARS-CoV-2 (COVID-19) S protein RBD (W436R), His (Tag) \\
\hline & SPD-S52H8 & SARS-CoV-2 & HEK293 & SARS-CoV-2 (COVID-19) S protein RBD (R408I), His (Tag) \\
\hline & SPD-C52H4 & SARS-CoV-2 & HEK293 & SARS-CoV-2 (COVID-19) S protein RBD (G476S), His (Tag) \\
\hline $\begin{array}{l}\text { S1 protein } \\
\text { CTD }\end{array}$ & $\mathrm{S} 1 \mathrm{D}-\mathrm{C} 52 \mathrm{H} 3$ & SARS-CoV-2 & HEK293 & SARS-CoV-2 (COVID-19) S1 protein CTD, His (Tag) \\
\hline \multirow{2}{*}{$\mathrm{S}$ protein } & SPN-C52H4 & SARS-CoV-2 & HEK293 & $\begin{array}{l}\text { SARS-CoV-2 (COVID-19) S protein (R683A, R685A), His } \\
\text { (Tag) }\end{array}$ \\
\hline & SPN-C52H8 & SARS-CoV-2 & HEK293 & $\begin{array}{l}\text { SARS-CoV-2 (COVID-19) S protein (R683A, R685A), His } \\
\text { (Tag), active trimer (MALS verified) }\end{array}$ \\
\hline $\begin{array}{l}\text { Envelope } \\
\text { protein }\end{array}$ & ENN-C5128 & SARS-CoV-2 & E.coli & SARS-CoV-2 (COVID-19) Envelope protein, His (Tag) \\
\hline $\begin{array}{l}\text { Papain-like } \\
\text { Protease }\end{array}$ & PAE-C5148 & SARS-CoV-2 & E.coli & $\begin{array}{l}\text { SARS-CoV-2 (COVID-19) Papain-like Protease Protein, His } \\
\text { (Tag) }\end{array}$ \\
\hline \multirow{2}{*}{$\begin{array}{l}\text { Nucleocapsi } \\
\text { d protein }\end{array}$} & NUN-C51H9 & SARS-CoV-2 & E.coli & SARS-CoV-2 (COVID-19) Nucleocapsid protein, His (Tag) \\
\hline & NUN-C5227 & SARS-CoV-2 & HEK293 & SARS-CoV-2 (COVID-19) Nucleocapsid protein, His (Tag) \\
\hline
\end{tabular}

Interestingly, the SARS-RBD counterpart in CoV2-RBD did not form close contact with the ACE2 in related simulations. It is worthwhile to mention that the sequence identity 
between CoV2-RBD and SARS-RBD is low in this loop region, suggesting the loop region might be partially responsible for the difference in the receptor binding. The hydrogen bonds among the CoV2-RBD and ACE2 can be extracted using VMD program. It can be discussed that the number of hydrogen bonds fluctuated over time. Similar trends can be observed in the other simulations, suggesting that the binding became stronger as the simulation progressed. This work has been done based on our theoretical works [19-73].

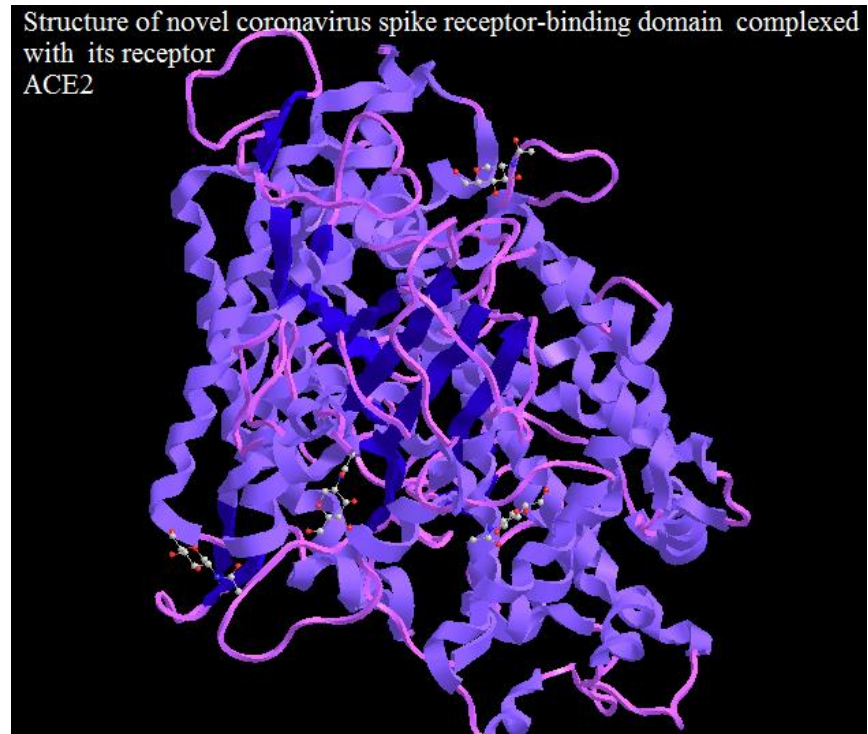

Figure 5. Structure of novel coronavirus spike receptor-binding domain complexed with its receptor ACE2.

\subsection{Involvement of Viroporins.}

Viroporin, or virus-encoded protein that mediates ion channel activity, has a crucial function in infection. It is specified via its hydrophobicity and its ability to diffusion inside membranes through oligomerization. These viruses consist of several multifunctional proteins from various viral groups that are predominately concentrated in RNA viruses. SARS-CoVs and various CoVs encode several viroporins, such as E protein, with extra viroporins encoded by accessory genes. The E proteins are refuged via some of CoVs, such as HCoV-229E, MERS-CoVs, and MHV [74-114].

Several important questions have to be discussed to be addressed: (1), for what reason?, does the accessory genes vary among $\mathrm{CoVs}$ from several genera, including $\alpha-\mathrm{CoV}, \beta-\mathrm{CoV}, \gamma-$ $\mathrm{CoV}$, and $\delta-\mathrm{CoV},(2)$, for what reason?, an increase or decrease does in the accessory genes from several CoVs contribute to the improved adaptability of CoVs to a new host or crossspecies transmission, (3), as CoVs employ diverse translational strategies that are not yet fully understood, do CoVs encode other unknown accessory proteins? (4), how do these genes derive in host ranges of CoVs, such as SARS-CoV-2 and PDCoV?,(5), what viral proteins interact with the accessories proteins, (6), do interactions appear among various accessory proteins from different CoVs with similar organs, such as PDCoV, PEDV, and TGEV, resulting in more serious co-infections? And finally, (7), for what reason? Delta variant of covid-19 is a concern compared with other variants. The answers to these questions will deepen our understanding of the function of accessory proteins in $\mathrm{CoVs}$ and facilitate the formulation of antiviral strategies and the development of effective vaccines. 


\section{Conclusions}

Coronavirus is extensively involved in the host immune response; therefore, studies on the functions of related proteins have become a major point in the $\mathrm{CoV}$ area. Accessory proteins share the various processes of the viral replication cycle and modulate host immunity, which consists of autophagy, apoptosis, innate immunity, and total stress response. However, the molecular mechanisms applied via accessory proteins remain largely unclear information, especially in the context of infection. In summary, future researches of accessory proteins from multifarious perspectives will facilitate a deeper understanding of the biology of these important viruses and will aid our ability to treat and prevent infections.

\section{Funding}

This research received no external funding.

\section{Acknowledgments}

The authors' thanks Kastamonu University and Islamic Azad University for providing computer and software equipment.

\section{Conflicts of Interest}

The authors declare no conflict of interest.

\section{References}

1. Woo, P.C.Y.; Lau, S.K.P.; Lam, C.S.F.; Lau, C.C.Y.; Tsang, A.K.L.; Lau, J.H.N.; Bai, R.; Teng, J.L.L.; Tsang, C.C.C.; Wang, M.; Zheng, B.-J.; Chan, K.-H.; Yuen, K.-Y. Discovery of seven novel Mammalian and avian coronaviruses in the genus deltacoronavirus supports bat coronaviruses as the gene source of alphacoronavirus and betacoronavirus and avian coronaviruses as the gene source of gammacoronavirus and deltacoronavirus. Journal of virology 2012, 86, 3995-4008, https://doi.org/10.1128/JVI.06540-11.

2. Zhang, J. Porcine deltacoronavirus: Overview of infection dynamics, diagnostic methods, prevalence and genetic evolution. Virus Res. 2016, 226, 71-84, https://doi.org/10.1016/j.virusres.2016.05.028.

3. Wille, M.; Holmes, E.C. Wild birds as reservoirs for diverse and abundant gamma- and deltacoronaviruses. FEMS Microbiol. Rev. 2020, 44, 631-644, https://doi.org/10.1093/femsre/fuaa026.

4. Jung, K.; Hu, H.; Saif, L.J. Calves are susceptible to infection with the newly emerged porcine deltacoronavirus, but not with the swine enteric alphacoronavirus, porcine epidemic diarrhea virus. Arch. Virol. 2017, 162, 2357-2362, https://doi.org/10.1007/s00705-017-3351-z.

5. Liang, Q.; Zhang, H.; Li, B.; Ding, Q.; Wang, Y.; Gao, W.; Guo, D.; Wei, Z.; Hu, H. Susceptibility of Chickens to Porcine Deltacoronavirus Infection. Viruses 2019, 11, https://doi.org/10.3390/v11060573.

6. Koetzner, C.A.; Kuo, L.; Goebel, S.J.; Dean, A.B.; Parker, M.M.; Masters, P.S. Accessory Protein 5a Is a Major Antagonist of the Antiviral Action of Interferon against Murine Coronavirus. J. Virol. 2010, 84, 8262-8274.

7. Boley, P.A.; Alhamo, M.A.; Lossie, G.; Yadav, K.K.; Vasquez-Lee, M.; Saif, L.J.; Kenney, S.P.; Boley, P. Porcine Deltacoronavirus Infection and Transmission in Poultry, United States1. Emerg. Infect. Dis. 2020, 26, 255-265, https://doi.org/10.3201/eid2602.190346.

8. Fang, P.; Fang, L.; Hong, Y.; Liu, X.; Dong, N.; Ma, P.; Bi, J.; Wang, D.; Xiao, S. Discovery of a novel accessory protein NS7a encoded by porcine deltacoronavirus. J. Gen. Virol. 2017, 98, 173-178, https://doi.org/10.1099/jgv.0.000690.

9. Fang, P.; Fang, L.; Liu, X.; Hong, Y.; Wang, Y.; Dong, N.; Ma, P.; Bi, J.; Wang, D.; Xiao, S. Identification and subcellular localization of porcine deltacoronavirus accessory protein NS6. Virology 2016, 499, 170177, https://dx.doi.org/10.1016\%2Fj.virol.2016.09.015.

10. Luo, J.; Fang, L.; Dong, N.; Fang, P.; . Ding, Z.; Wang, D.; Chen, H.; Xiao, S. Porcine deltacoronavirus (PDCoV) infection suppresses RIG-I-mediated interferon-beta production. Virology 2016, 495, 10-17, https://doi.org/10.1016/j.virol.2016.04.025.

11. Fang, P.; Fang, L.; Ren, J.; Hong, Y.; Liu, X.; Zhao, Y.; Wang, D.; Peng, G.; Xiao, S. Porcine Deltacoronavirus Accessory Protein NS6 Antagonizes Interferon Beta Production by Interfering with the Binding of RIG-I/MDA5 to Double-Stranded RNA. J. Virol. 2018, 92, e00712-18, https://doi.org/10.1128/jvi.00712-18. 
12. Fang, P.; Fang, L.; Xia, S.; Ren, J.; Zhang, J.; Bai, D.; Zhou, Y.; Peng, G.; Zhao, S.; Xiao, S. Porcine Deltacoronavirus Accessory Protein NS7a Antagonizes IFN-beta Production by Competing With TRAF3 and IRF3 for Binding to IKKepsilon. Front. Cell. Infect. Microbiol. 2020, 10, https://dx.doi.org/10.3389\%2Ffcimb.2020.00257.

13. Jung, K.; Miyazaki, A.; Hu, H.; Saif, L.J. Susceptibility of porcine IPEC-J2 intestinal epithelial cells to infection with porcine deltacoronavirus (PDCoV) and serum cytokine responses of gnotobiotic pigs to acute infection with IPEC-J2 cell culture-passaged PDCoV. Vet. Microbiol. 2018, 221, 49-58, https://doi.org/10.1016/j.vetmic.2018.05.019.

14. Lee, Y.J.; Lee, C. Porcine deltacoronavirus induces caspase-dependent apoptosis through activation of the cytochrome c -mediated intrinsic mitochondrial pathway. Virus Res. 2018, 253, 112-123, https://doi.org/10.1016/j.virusres.2018.06.008.

15. Jung, K.; Hu, H.; Saif, L.J. Porcine deltacoronavirus induces apoptosis in swine testicular and LLC porcine kidney cell lines in vitro but not in infected intestinal enterocytes in vivo. Vet. Microbiol. 2016, 182, 57-63, https://doi.org/10.1016/j.vetmic.2015.10.022.

16. Qin, P.; Du, E.-Z.; Luo, W.-T.; Yang, Y.-L.; Zhang, Y.-Q.; Wang, B.; Huang, Y.-W. Characteristics of the Life Cycle of Porcine Deltacoronavirus (PDCoV) In Vitro: Replication Kinetics, Cellular Ultrastructure and Virion Morphology, and Evidence of Inducing Autophagy. Viruses 2019, 11, https://dx.doi.org/10.3390\%2Fv11050455.

17. Bai, D.; Fang, L.; Xia, S.; Ke, W.; Wang, J.; Wu, X.; Fang, P.; Xiao, S. Porcine deltacoronavirus (PDCoV) modulates calcium influx to favor viral replication. Virology 2020, 539, 38-48, https://doi.org/10.1016/j.virol.2019.10.011.

18. Zhang, M.; Li, W.; Zhou, P.; Liu, D.; Luo, R.; Jongkaewwattana, A.; He, Q. Genetic manipulation of porcine deltacoronavirus reveals insights into NS6 and NS7 functions: A novel strategy for vaccine design. Emerg. Microbes Infect. 2019, 9, 20-31, https://dx.doi.org/10.1080\%2F22221751.2019.1701391.

19. Mollaamin, F.; Monajjemi, M. DFT outlook of solvent effect on function of nano bioorganic drugs. Phys. Chem. Liq. 2012, 50, 596-604, https://doi.org/10.1080/00319104.2011.646444.

20. Mollaamin, F.; Gharibe, S.; Monajjemi, M. Synthesis of various nano and micro ZnSe morphologies by using hydrothermal method. International Journal of the Physical Sciences 2011, 6, 1496-1500.

21. Monajjemi, M. Graphene/(h-BN) n/X-doped graphene as anode material in lithium ion batteries $(\mathrm{X}=\mathrm{Li}, \mathrm{Be}$, B and N). Macedonian Journal of Chemistry and Chemical Engineering 2017, 36, 101-118.

22. Monajjemi, M. Cell membrane causes the lipid bilayers to behave as variable capacitors: A resonance with self-induction of helical proteins. Biophys. Chem. 2015, 207, 114-127, https://doi.org/10.1016/j.bpc.2015.10.003.

23. Monajjemi, M. Study of CD5+ Ions and Deuterated Variants $(\mathrm{CHxD}(5-\mathrm{x})+)$ : An Artefactual Rotation. Russian Journal of Physical Chemistry A 2018, 92, 2215-2226, https://doi.org/10.1134/S0036024418110286.

24. Monajjemi, M. Liquid-phase exfoliation (LPE) of graphite towards graphene: An ab initio study. J. Mol. Liq. 2017, 230, 461-472, https://doi.org/10.1016/j.molliq.2017.01.044.

25. Jalilian, H.; Monajjemi, M. Capacitor simulation including of $\mathrm{X}$-doped graphene $(\mathrm{X}=\mathrm{Li}, \mathrm{Be}, \mathrm{B})$ as two electrodes and $(\mathrm{h}-\mathrm{BN}) \mathrm{m}(\mathrm{m}=1-4)$ as the insulator. Jpn. J. Appl. Phys. 2015, 54, https://doi.org/10.7567/jjap.54.085101.

26. Ardalan, T.; Ardalan, P.; Monajjemi, M. Nano Theoretical Study of a C16 Cluster as a Novel Material for Vitamin C Carrier. Fullerenes, Nanotubes and Carbon Nanostructures 2014, 22, 687-708, https://doi.org/10.1080/1536383X.2012.717561.

27. Mahdavian, L.; Monajjemi, M.; Mangkorntong, N. Sensor Response to Alcohol and Chemical Mechanism of Carbon Nanotube Gas Sensors. Fullerenes, Nanotubes and Carbon Nanostructures 2009, 17, 484-495, https://doi.org/10.1080/15363830903130044.

28. Monajjemi, M.; Najafpour, J. Charge Density Discrepancy Between NBO and QTAIM in Single-wall Armchair Carbon Nanotubes. Fullerenes, Nanotubes and Carbon Nanostructures 2014, 22, 575-594, https://doi.org/10.1080/1536383X.2012.702161.

29. Monajjemi, M.; Seyed Hosseini, M. Non Bonded Interaction of B16N16 Nano Ring with Copper Cations in Point of Crystal Fields. Journal of Computational and Theoretical Nanoscience 2013, 10, 2473-2477, https://doi.org/10.1166/jctn.2013.3233.

30. Monajjemi, M.; Mahdavian, L.; Mollaamin, F. Characterization of nanocrystalline silicon germanium film and nanotube in adsorption gas by Monte Carlo and Langevin dynamic simulation. Bulletin of the Chemical Society of Ethiopia 2008, 22, 277-286, https://doi.org/10.4314/bcse.v22i2.61299.

31. Lee, V.S.; Nimmanpipug, P.; Mollaamin, F.; Kungwan, N.; Thanasanvorakun, S.; Monajjemi, M. Investigation of single wall carbon nanotubes electrical properties and normal mode analysis: Dielectric effects. Russian Journal of Physical Chemistry A 2009, 83, 2288-2296, https://doi.org/10.1134/S0036024409130184.

32. Mollaamin, F.; Najafpour, J.; Ghadami, S.; Akrami, M.S.; Monajjemi, M. The electromagnetic feature of B15N15Hx (x = 0, 4, 8, 12, 16, and 20) nano rings:Quantum theory of atoms in molecules/NMR approach. Journal of Computational and Theoretical Nanoscience 2014, 11, 1290-1298. 
33. Monajjemi, M.; Mahdavian, L.; Mollaamin, F.; Honarparvar, B. Thermodynamic Investigation of Enol $\leftrightarrow$ Keto Tautomerism for Alcohol Sensors Based on Carbon Nanotubes as Chemical Sensors. Fullerenes, Nanotubes and Carbon Nanostructures 2010, 18, 45-55, https://doi.org/10.1080/15363830903291564.

34. Monajjemi, M.; Ghiasi, R.; Sadjadi, M.A.S. Metal-stabilized rare tautomers: N4 metalated cytosine $(\mathrm{M}=\mathrm{Li}+$, $\mathrm{Na}+, \mathrm{K}+, \mathrm{Rb}+$ and $\mathrm{Cs}+)$, theoretical views. Appl. Organomet. Chem. 2003, 17, 635-640, https://doi.org/10.1002/aoc.469.

35. Ilkhani, A.R.; Monajjemi, M. The pseudo Jahn-Teller effect of puckering in pentatomic unsaturated rings C4AE5, A=N, P, As, E=H, F, Cl. Computational and Theoretical Chemistry 2015, 1074, 19-25, http://dx.doi.org/10.1016\%2Fj.comptc.2015.10.006.

36. Monajjemi, M. Non-covalent attraction of $\mathrm{B} 2 \mathrm{~N}(-, 0)$ and repulsion of $\mathrm{B} 2 \mathrm{~N}(+)$ in the BnNnring: a quantum rotatory due to an external field. Theor. Chem. Acc. 2015, 134, https://doi.org/10.1007/s00214-015-1668-9.

37. Monajjemi, M.; Naderi, F.; Mollaamin, F.; Khaleghian, M. Drug design outlook by calculation of second virial coefficient as a nano study. Journal of the Mexican Chemical Society 2012, 56, 207-211, https://doi.org/10.29356/jmcs.v56i2.323.

38. Monajjemi, M.; Bagheri, S.; Moosavi, M.S.; Moradiyeh, N.; Zakeri, M.; Attarikhasraghi, N.; Saghayimarouf, N.; Niyatzadeh, G.; Shekarkhand, M.; Khalilimofrad, M.S.; Ahmadin, H.; Ahadi, M. Symmetry Breaking of B2N $(-, 0,+)$ : An Aspect of the Electric Potential and Atomic Charges. Molecules 2015, 20, https://doi.org/10.3390/molecules201219769.

39. Monajjemi, M.; Mohammadian, N.T. S-NICS: An Aromaticity Criterion for Nano Molecules. Journal of Computational and Theoretical Nanoscience 2015, 12, 4895-4914, https://doi.org/10.1166/jctn.2015.4458.

40. Monajjemi, M.; Ketabi, S.; Hashemian Zadeh, M.; Amiri, A. Simulation of DNA bases in water: Comparison of the Monte Carlo algorithm with molecular mechanics force fields. Biochemistry (Moscow) 2006, 71, S1S8, https://doi.org/10.1134/s0006297906130013.

41. Monajjemi, M.; Lee, V.S.; Khaleghian, M.; Honarparvar, B.; Mollaamin, F. Theoretical Description of Electromagnetic Nonbonded Interactions of Radical, Cationic, and Anionic NH2BHNBHNH2 Inside of the B18N18 Nanoring. The Journal of Physical Chemistry C 2010, 114, 15315-15330, https://doi.org/10.1021/jp104274z.

42. Monajjemi, M.; Boggs, J.E. A New Generation of BnNn Rings as a Supplement to Boron Nitride Tubes and Cages. The Journal of Physical Chemistry A 2013, 117, 1670-1684, https://doi.org/10.1021/jp312073q.

43. Monajjemi, M. Non bonded interaction between BnNn (stator) and BN(-,0,+)B (rotor) systems: A quantum rotation in IR region. Chem. Phys. 2013, 425, 29-45, https://doi.org/10.1016/j.chemphys.2013.07.014.

44. Monajjemi, M.; Wayne, R.; Boggs, J.E. NMR contour maps as a new parameter of carboxyl's OH groups in amino acids recognition: A reason of tRNA-amino acid conjugation. Chem. Phys. 2014, 433, 1-11, https://doi.org/10.1016/j.chemphys.2014.01.017.

45. Monajjemi, M. Quantum investigation of non-bonded interaction between the B15N15 ring and BH2NBH2 (radical, cation, anion) systems: a nano molecularmotor. Struct. Chem. 2012, 23, 551-580, http://dx.doi.org/10.1007/s11224-011-9895-8.

46. Monajjemi, M. Metal-doped graphene layers composed with boron nitride-graphene as an insulator: a nanocapacitor. J. Mol. Model. 2014, 20, https://doi.org/10.1007/s00894-014-2507-y.

47. Mollaamin, F.; Monajjemi, M.; Mehrzad, J. Molecular Modeling Investigation of an Anti-cancer Agent Joint to SWCNT Using Theoretical Methods. Fullerenes, Nanotubes and Carbon Nanostructures 2014, 22, 738751, https://doi.org/10.1080/1536383X.2012.731582.

48. Monajjemi, M.; Ketabi, S.; Amiri, A. Monte Carlo simulation study of melittin: Protein folding and temperature dependence. Russian Journal of Physical Chemistry 2006, 80, S55-S62, https://doi.org/10.1134/S0036024406130103.

49. Monajjemi, M.; Heshmata, M.; Haeria, H.H. QM/MM model study on properties and structure of some antibiotics in gas phase: Comparison of energy and NMR chemical shift. Biochemistry (Moscow) 2006, 71, S113-S122, https://doi.org/10.1134/S0006297906130190.

50. Monajjemi, M.; Afsharnezhad, S.; Jaafari, M.R.; Abdolahi, T.; Nikosade, A.; Monajemi, H. NMR shielding and a thermodynamic study of the effect of environmental exposure to petrochemical solvent on DPPC, an important component of lung surfactant. Russian Journal of Physical Chemistry A 2007, 81, 1956-1963, https://doi.org/10.1134/S0036024407120096.

51. Mollaamin, F.; Noei, M.; Monajjemi, M.; Rasoolzadeh, R. Nano theoretical studies of fMET-tRNA structuren in protein synthesis of prokaryotes and its comparison with the structure of fALA-tRNA. African Journal of Microbiology Research 2011, 5, 2667-2674, https://doi.org/10.5897/AJMR11.310.

52. Monajjemi, M.; Heshmat, M.; Haeri, H.H.; Kaveh, F. Theoretical study of vitamin properties from combined QM-MM methods: Comparison of chemical shifts and energy. Russian Journal of Physical Chemistry 2006, 80, https://doi.org/10.1134/S0036024406070119.

53. Monajjemi, M.; Chahkandi, B. Theoretical investigation of hydrogen bonding in Watson-Crick, Hoogestein and their reversed and other models: comparison and analysis for configurations of adenine-thymine base pairs in 9 models. Journal of Molecular Structure: THEOCHEM 2005, 714, 43-60, https://doi.org/10.1016/j.theochem.2004.09.048. 
54. Monajjemi, M.; Honarparvar, B.; Haeri, H.H.; Heshmat, M. An ab initio quantum chemical investigation of solvent-induced effect on 14N-NQR parameters of alanine, glycine, valine, and serine using a polarizable continuum model. Russian Journal of Physical Chemistry 2006, 80, https://doi.org/10.1134/S0036024406130073.

55. Monajjemi, M.; Farahani, N.; Mollaamin, F. Thermodynamic study of solvent effects on nanostructures: phosphatidylserine and phosphatidylinositol membranes. Phys. Chem. Liq. 2012, 50, 161-172, https://doi.org/10.1080/00319104.2010.527842.

56. Monajjemi, M.; Ahmadianarog, M. Carbon Nanotube as a Deliver for Sulforaphane in Broccoli Vegetable in Point of Nuclear Magnetic Resonance and Natural Bond Orbital Specifications. Journal of Computational and Theoretical Nanoscience 2014, 11, 1465-1471, https://doi.org/10.1166/jctn.2014.3519.

57. Monajjemi, M.; Ghiasi, R.; Ketabi, S.; Passdar, H.; Mollaamin, F. A Theoretical Study of Metal-Stabilised Rare Tautomers Stability: N4 Metalated Cytosine (M=Be2+, Mg2+, Ca2+, $\mathrm{Sr} 2+$ and $\mathrm{Ba} 2+)$ in Gas Phase and Different Solvents. Journal of Chemical Research 2004, 2004, 11-18, https://doi.org/10.3184/030823404323000648.

58. Monajjemi, M.; Baei, M.T.; Mollaamin, F. Quantum mechanic study of hydrogen chemisorptions on nanocluster vanadium surface. Russian Journal of Inorganic Chemistry 2008, 53, 1430-1437, https://doi.org/10.1134/S0036023608090143.

59. Mollaamin, F.; Baei, M.T.; Monajjemi, M.; Zhiani, R.; Honarparvar, B. A DFT study of hydrogen chemisorption on V (100) surfaces. Russian Journal of Physical Chemistry A, Focus on Chemistry 2008, 82, 2354-2361, https://doi.org/10.1134/S0036024408130323.

60. Monajjemi, M.; Honarparvar, B.; Nasseri, S.M.; Khaleghian, M. NQR and NMR study of hydrogen bonding interactions in anhydrous and monohydrated guanine cluster model: A computational study. J. Struct. Chem. 2009, 50, 67-77, https://doi.org/10.1007/s10947-009-0009-z.

61. Monajjemi, M.; Aghaie, H.; Naderi, F. Thermodynamic study of interaction of TSPP, CoTsPc, and FeTsPc with calf thymus DNA. Biochemistry (Moscow) 2007, 72, 652-657, https://doi.org/10.1134/S0006297907060089.

62. Monajjemi, M.; Heshmat, M.; Aghaei, H.; Ahmadi, R.; Zare, K. Solvent effect on 14N NMR shielding of glycine, serine, leucine, and threonine: Comparison between chemical shifts and energy versus dielectric constant. Bulletin of the Chemical Society of Ethiopia 2007, 21, 111-116, https://doi.org/10.4314/bcse.v21i1.61387.

63. Monajjemi, M.; Rajaeian, E.; Mollaamin, F.; Naderi, F.; Saki, S. Investigation of NMR shielding tensors in 1,3 dipolar cycloadditions: solvents dielectric effect. Phys. Chem. Liq. 2008, 46, 299-306, https://doi.org/10.1080/00319100601124369.

64. Mollaamin, F.; Varmaghani, Z.; Monajjemi, M. Dielectric effect on thermodynamic properties in vinblastine by DFT/Onsager modelling. Phys. Chem. Liq. 2011, 49, 318-336, https://doi.org/10.1080/00319100903456121.

65. Monajjemi, M.; Honaparvar, B.; Khalili Hadad, B.; Ilkhani, A.; Mollaamin, F. Thermo-Chemical Investigation and NBO Analysis of Some anxileotic as Nano- Drugs. African journal of pharmacy and pharmacology 2010, 4, 521-529.

66. Monajjemi, M.; Khaleghian, M.; Mollaamin, F. Theoretical study of the intermolecular potential energy and second virial coefficient in the mixtures of $\mathrm{CH} 4$ and $\mathrm{Kr}$ gases: a comparison with experimental data. Mol. Simul. 2010, 36, 865-870, https://doi.org/10.1080/08927022.2010.489557.

67. Monajjemi, M.; Khosravi, M.; Honarparvar, B.; Mollaamin, F. Substituent and solvent effects on the structural bioactivity and anticancer characteristic of catechin as a bioactive constituent of green tea. Int. J. Quantum Chem 2011, 111, 2771-2777, https://doi.org/10.1002/qua.22612.

68. Tahan, A.; Monajjemi, M. Solvent Dielectric Effect and Side Chain Mutation on the Structural Stability of Burkholderia cepacia Lipase Active Site: A Quantum Mechanical/Molecular Mechanics Study. Acta Biotheor. 2011, 59, 291-312, https://doi.org/10.1007/s10441-011-9137-X.

69. Monajjemi, M.; Khaleghian, M. EPR Study of Electronic Structure of [CoF6]3-and B18N18 Nano Ring Field Effects on Octahedral Complex. J. Cluster Sci. 2011, 22, 673-692, https://doi.org/10.1007/s10876-011-04142.

70. Monajjemi, M.; Mollaamin, F. Molecular Modeling Study of Drug-DNA Combined to Single Walled Carbon Nanotube. J. Cluster Sci. 2012, 23, 259-272, https://doi.org/10.1007/s10876-011-0426-y.

71. Mollaamin, F.; Monajjemi, M. Fractal Dimension on Carbon Nanotube-Polymer Composite Materials Using Percolation Theory. Journal of Computational and Theoretical Nanoscience 2012, 9, 597-601, https://doi.org/10.1166/jctn.2012.2067.

72. Mahdavian, L.; Monajjemi, M. Alcohol sensors based on SWNT as chemical sensors: Monte Carlo and Langevin dynamics simulation. Microelectron. $\quad J . \quad \mathbf{2 0 1 0}, \quad 41, \quad 142-149$, https://doi.org/10.1016/j.mejo.2010.01.011.

73. Monajjemi, M.; Falahati, M.; Mollaamin, F. Computational investigation on alcohol nanosensors in combination with carbon nanotube: a Monte Carlo and ab initio simulation. Ionics 2013, 19, 155-164, https://doi.org/10.1007/s11581-012-0708-x. 
74. Li, R.; Pei, S.; Chen, B.; Song, Y.; Zhang, T.; Yang, W.; Shaman, J. Substantial undocumented infection facilitates the rapid dissemination of novel coronavirus (SARS-CoV-2). Science 2020, 368, 489-493, https://doi.org/10.1126/science.abb3221.

75. Jung, K.; Saif, L.J.; Wang, Q. Porcine epidemic diarrhea virus (PEDV): An update on etiology, transmission, pathogenesis, and prevention and control. Virus Res. 2020, 286, https://dx.doi.org/10.1016\%2Fj.virusres.2020.198045.

76. Shi, J.; Wen, Z.; Zhong, G.; Yang, H.; Wang, C.; Huang, B.; Liu, R.; He, X.; Shuai, L.; Sun, Z.; Zhao, Y.; Liu, P.; Liang, L.; Cui, P.; Wang, J.; Zhang, X.; Guan, Y.; Tan, W.; Wu, G.; Chen, H.; Bu, Z. Susceptibility of ferrets, cats, dogs, and other domesticated animals to SARS-coronavirus 2. Science 2020, 368, 1016-1020. https://doi.org/10.1126/science.abb7015.

77. Yang, Y.-L.; Yu, J.-Q.; Huang, Y.-W. Swine enteric alphacoronavirus (swine acute diarrhea syndrome coronavirus): An update three years after its discovery. Virus Res. 2020, 285, https://dx.doi.org/10.1016\%2Fj.virusres.2020.198024.

78. Legnardi, M.; Tucciarone, C.M.; Franzo, G.; Cecchinato, M. Infectious Bronchitis Virus Evolution, Diagnosis and Control. Vet. Sci. 2020, 7, https://dx.doi.org/10.3390\%2Fvetsci7020079.

79. Lednicky, J.A.; Tagliamonte, M.S.; White, S.K.; Elbadry, M.A.; Alam, M.M.; Stephenson, C.J.; Bonny, T.S.; Loeb, J.C.; Telisma, T.; Chavannes, S.; Ostrov, D.A.; Mavian, C.; De Rochars, V.M.B.; Salemi, M.; Morris, J.G. Emergence of porcine delta-coronavirus pathogenic infections among children in Haiti through independent zoonoses and convergent evolution. medRxiv 2021, https://doi.org/10.1101/2021.03.19.21253391.

80. Michel, C.J.; Mayer, C.; Poch, O.; Thompson, J.D. Characterization of accessory genes in coronavirus genomes. Virol. J. 2020, 17, 1-13, https://doi.org/10.1186/s12985-020-01402-1.

81. Blanco-Melo, D.; Nilsson-Payant, B.E.; Liu, W.C.; Uhl, S.; Hoagland, D.; Møller, R.; Jordan, T.X.; Oishi, K.; Panis, M.; Sachs, D.; Wang, T.T.; Schwartz, R.E.; Lim, J.K.; Albrecht, R.A.; tenOever, B.R. Imbalanced Host Response to SARS-CoV-2 Drives Development of COVID-19. Cell 2020, 181, 1036-1045.e1039, https://doi.org/10.1016/j.cell.2020.04.026.

82. Gordon, D.E.; Jang, G.M.; Bouhaddou, M.; Xu, J.; Obernier, K.; White, K.M.; O’Meara, M.J.; Rezelj, V.V.; Guo, J.Z.; Swaney, D.L.; Tummino, T.A.; Hüttenhain, R.; Kaake, R.M.; Richards, A.L.; Tutuncuoglu, B.; Foussard, H.; Batra, J.; Haas, K.; Modak, M.; Kim, M.; Haas, P.; Polacco, B.J.; Braberg, H.; Fabius, J.M.; Eckhardt, M.; Soucheray, M.; Bennett, M.J.; Cakir, M.; McGregor, M.J.; Li, Q.; Meyer, B.; Roesch, F.; Vallet, T.; Mac Kain, A.; Miorin, L.; Moreno, E.; Naing, Z.Z.C.; Zhou, Y.; Peng, S.; Shi, Y.; Zhang, Z.; Shen, W.; Kirby, I.T.; Melnyk, J.E.; Chorba, J.S.; Lou, K.; Dai, S.A.; Barrio-Hernandez, I.; Memon, D.; HernandezArmenta, C.; Lyu, J.; Mathy, C.J.P.; Perica, T.; Pilla, K.B.; Ganesan, S.J.; Saltzberg, D.J.; Rakesh, R.; Liu, X.; Rosenthal, S.B.; Calviello, L.; Venkataramanan, S.; Liboy-Lugo, J.; Lin, Y.; Huang, X.-P.; Liu, Y.; Wankowicz, S.A.; Bohn, M.; Safari, M.; Ugur, F.S.; Koh, C.; Savar, N.S.; Tran, Q.D.; Shengjuler, D.; Fletcher, S.J.; O’Neal, M.C.; Cai, Y.; Chang, J.C.J.; Broadhurst, D.J.; Klippsten, S.; Sharp, P.P.; Wenzell, N.A.; Kuzuoglu-Ozturk, D.; Wang, H.-Y.; Trenker, R.; Young, J.M.; Cavero, D.A.; Hiatt, J.; Roth, T.L.; Rathore, U.; Subramanian, A.; Noack, J.; Hubert, M.; Stroud, R.M.; Frankel, A.D.; Rosenberg, O.S.; Verba, K.A.; Agard, D.A.; Ott, M.; Emerman, M.; Jura, N.; von Zastrow, M.; Verdin, E.; Ashworth, A.; Schwartz, O.; d'Enfert, C.; Mukherjee, S.; Jacobson, M.; Malik, H.S.; Fujimori, D.G.; Ideker, T.; Craik, C.S.; Floor, S.N.; Fraser, J.S.; Gross, J.D.; Sali, A.; Roth, B.L.; Ruggero, D.; Taunton, J.; Kortemme, T.; Beltrao, P.; Vignuzzi, M.; García-Sastre, A.; Shokat, K.M.; Shoichet, B.K.; Krogan, N.J. A SARS-CoV-2 protein interaction map reveals targets for drug repurposing. Nature 2020, 583, 459-468, https://doi.org/10.1038/s41586-020-2286-9.

83. Wu, J.; Shi, Y.; Pan, X.; Wu, S.; Hou, R.; Zhang, Y.; Zhong, T.; Tang, H.; Du, W.; Wang, L.; Wo, J.; Mu, J.; Qiu, Y.; Yang, K.; Zhang, L.K.; Ye, B.C.; Qi, N. SARS-CoV-2 ORF9b inhibits RIG-I-MAVS antiviral signaling by interrupting K63-linked ubiquitination of NEMO. Cell Rep 2021, 34, https://doi.org/10.1016/j.celrep.2021.108761.

84. Wong, L.R.; Ye, Z.W.; Lui, P.Y.; Zheng, X.; Yuan, S.; Zhu, L.; Fung, S.Y.; Yuen, K.S.; Siu, K.L.; Yeung, M.L.; Cai, Z.; Woo, P.C.; Yuen, K.Y.; Chan, C.P.; Jin, D.Y. Middle East Respiratory Syndrome Coronavirus ORF8b Accessory Protein Suppresses Type I IFN Expression by Impeding HSP70-Dependent Activation of IRF3 Kinase IKKe. Journal of immunology (Baltimore, Md. : 1950) 2020, 205, 1564-1579, https://doi.org/10.4049/jimmunol.1901489.

85. Li, J.Y.; Liao, C.H.; Wang, Q.; Tan, Y.J.; Luo, R.; Qiu, Y.; Ge, X.Y. The ORF6, ORF8 and nucleocapsid proteins of SARS-CoV-2 inhibit type I interferon signaling pathway. Virus Res. 2020, 286, https://doi.org/10.1016/j.virusres.2020.198074.

86. Lei, X.; Dong, X.; Ma, R.; Wang, W.; Xiao, X.; Tian, Z.; Wang, C.; Wang, Y.; Li, L.; Ren, L.; Guo, F.; Zhao, Z.; Zhou, Z.; Xiang, Z.; Wang, J. Activation and evasion of type I interferon responses by SARS-CoV-2. Nature Communications 2020, 11, https://doi.org/10.1038/s41467-020-17665-9.

87. Konno, Y.; Kimura, I.; Uriu, K.; Fukushi, M.; Irie, T.; Koyanagi, Y.; Sauter, D.; Gifford, R.J.; Nakagawa, S.; Sato, K. SARS-CoV-2 ORF3b Is a Potent Interferon Antagonist Whose Activity Is Increased by a Naturally Occurring Elongation Variant. Cell Reports 2020, 32, 108-185, https://doi.org/10.1016/j.celrep.2020.108185. 
88. Flower, T.G.; Buffalo, C.Z.; Hooy, R.M.; Allaire, M.; Ren, X.; Hurley, J.H. Structure of SARS-CoV-2 ORF8, a rapidly evolving immune evasion protein. Proc. Natl. Acad. Sci. USA 2021, 118, https://doi.org/10.1073/pnas.2021785118.

89. Miorin, L.; Kehrer, T.; Sanchez-Aparicio, M.T.; Zhang, K.; Cohen, P.; Patel, R.S.; Cupic, A.; Makio, T.; Mei, M.; Moreno, E.; et al. SARS-CoV-2 Orf6 hijacks Nup98 to block STAT nuclear import and antagonize interferon signaling. Proc. Nat. Acad. Sci. USA 2020, 117, 28344-28354, https://doi.org/10.1073/pnas.2016650117.

90. Shang, J.; Han, N.; Chen, Z.; Peng, Y.; Li, L.; Zhou, H.; Ji, C.; Meng, J.; Jiang, T.; Wu, A. Compositional diversity and evolutionary pattern of coronavirus accessory proteins. Briefings Bioinform. 2021, 22, 12671278, https://doi.org/10.1093/bib/bbaa262.

91. Zhou, F.; Yu, T.; Du, R.; Fan, G.; Liu, Y.; Liu, Z.; Xiang, J.; Wang, Y.; Song, B.; Gu, X.; Guan, L.; Wei, Y.; Li, H.; Wu, X.; Xu, J.; Tu, S.; Zhang, Y.; Chen, H.; Cao, B. Clinical course and risk factors for mortality of adult inpatients with COVID-19 in Wuhan, China: a retrospective cohort study. Lancet (London, England) 2020, 395, 1054-1062, https://doi.org/10.1016/s0140-6736(20)30566-3.

92. Freeman, T.L.; Swartz, T.H. Targeting the NLRP3 Inflammasome in Severe COVID-19. Front. Immunol. 2020, 11, https://dx.doi.org/10.3389\%2Ffimmu.2020.01518.

93. Sendler, M.; van den Brandt, C.; Glaubitz, J.; Wilden, A.; Golchert, J.; Weiss, F.U.; Homuth, G.; De Freitas Chama, L.L.; Mishra, N.; Mahajan, U.M.; Bossaller, L.; Völker, U.; Bröker, B.M.; Mayerle, J.; Lerch, M.M. NLRP3 Inflammasome Regulates Development of Systemic Inflammatory Response and Compensatory Anti-Inflammatory Response Syndromes in Mice With Acute Pancreatitis. Gastroenterology 2020, 158, 253269.e214, https://doi.org/10.1053/j.gastro.2019.09.040.

94. Paniri, A.; Akhavan-Niaki, H. Emerging role of IL-6 and NLRP3 inflammasome as potential therapeutic targets to combat COVID-19: Role of IncRNAs in cytokine storm modulation. Life Sci. 2020, 257, https://dx.doi.org/10.1016\%2Fj.lfs.2020.118114.

95. Kaewborisuth, C.; Koonpaew, S.; Srisutthisamphan, K.; Viriyakitkosol, R.; Jaru-Ampornpan, P.; Jongkaewwattana, A. PEDV ORF3 Independently Regulates IkappaB Kinase beta-Mediated NF-kappaB and IFN-beta Promoter Activities. Pathogens 2020, 9, https://doi.org/10.3390/pathogens9050376.

96. Wu, Z.; Cheng, L.; Xu, J.; Li, P.; Li, X.; Zou, D.; Zhang, Y.; Wang, X.; Wu, X.; Shen, Y.; Li, Y.; Yao, L.; Guo, D.; Li, L.; Xiao, L.; Song, B.; Ma, J.; Liu, X.; Xu, S.; Xu, X.; Zhang, H.; Zheng, L.; Cao, H. The accessory protein ORF3 of porcine epidemic diarrhea virus inhibits cellular interleukin-6 and interleukin-8 productions by blocking the nuclear factor- $\mathrm{\kappa B}$ p65 activation. Veterinary Microbiology 2020, 251, https://doi.org/10.1016/j.vetmic.2020.108892.

97. Banerjee, A.; Czinn, S.J.; Reiter, R.J.; Blanchard, T.G. Crosstalk between endoplasmic reticulum stress and antiviral activities: A novel therapeutic target for COVID-19. Life Sci 2020, 255, https://doi.org/10.1016/j.lfs.2020.117842.

98. Köseler, A.; Sabirli, R.; Gören, T.; Türkçüer, I.; Kurt, Ö. Endoplasmic Reticulum Stress Markers in SARSCOV-2 Infection and Pneumonia: Case-Control Study. In Vivo 2020, 34, 1645-1650, https://doi.org/10.21873/invivo.11956.

99. García-Pérez, B.E.; González-Rojas, J.A.; Salazar, M.I.; Torres-Torres, C.; Castrejón-Jiménez, N.S. Taming the Autophagy as a Strategy for Treating COVID-19. Cells 2020, 9, https://doi.org/10.3390/cells9122679.

100. Domdom, M.-A.; Brest, P.; Grosjean, I.; Roméo, B.; Landi, M.T.; Gal, J.; Klionsky, D.J.; Hofman, P.; Mograbi, B. A multifactorial score including autophagy for prognosis and care of COVID-19 patients. Autophagy 2020, 16, 2276-2281, https://doi.org/10.1080/15548627.2020.1844433.

101.Gorshkov, K.; Chen, C.Z.; Bostwick, R.; Rasmussen, L.; Xu, M.; Pradhan, M.; Tran, B.N.; Zhu, W.; Shamim, K.; Huang, W.; Hu, X.; Shen, M.; Klumpp-Thomas, C.; Itkin, Z.; Shinn, P.; Simeonov, A.; Michael, S.; Hall, M.D.; Lo, D.C.; Zheng, W. The SARS-CoV-2 cytopathic effect is blocked with autophagy modulators. bioRxiv : the preprint server for biology 2020, https://doi.org/10.1101/2020.05.16.091520.

102.Ren, Y.; Shu, T.; Wu, D.; Mu, J.; Wang, C.; Huang, M.; Han, Y.; Zhang, X.-Y.; Zhou, W.; Qiu, Y.; Zhou, X. The ORF3a protein of SARS-CoV-2 induces apoptosis in cells. Cellular \& Molecular Immunology 2020, 17, 881-883, https://doi.org/10.1038/s41423-020-0485-9.

103.Si, F.; Hu, X.; Wang, C.; Chen, B.; Wang, R.; Dong, S.; Yu, R.; Li, Z. Porcine Epidemic Diarrhea Virus (PEDV) ORF3 Enhances Viral Proliferation by Inhibiting Apoptosis of Infected Cells. Viruses 2020, 12, https://dx.doi.org/10.3390\%2Fv12020214.

104. Singh Tomar, P.P.; Arkin, I.T. SARS-CoV-2 E protein is a potential ion channel that can be inhibited by Gliclazide and Memantine. Biochem. Biophys. Res. Commun. 2020, 530, 10-14, https://doi.org/10.1016/j.bbrc.2020.05.206.

105.Bai, D.; Fang, L.; Xia, S.; Ke, W.; Wang, J.; Wu, X.; Fang, P.; Xiao, S. Porcine deltacoronavirus (PDCoV) modulates calcium influx to favor viral replication. Virology 2020, 539, 38-48, https://doi.org/10.1016/j.virol.2019.10.011.

106. Ye, C.; Chiem, K.; Park, J.G.; Oladunni, F.; Platt, R.N., 2nd; Anderson, T.; Almazan, F.; de la Torre, J.C.; Martinez-Sobrido, L. Rescue of SARS-CoV-2 from a Single Bacterial Artificial Chromosome. mBio 2020, 11, e02168-20, https://doi.org/10.1128/mBio.02168-20. 
107.Xie, X.; Muruato, A.; Lokugamage, K.G.; Narayanan, K.; Zhang, X.; Zou, J.; Liu, J.; Schindewolf, C.; Bopp, N.E.; Aguilar, P.V.; Plante, K.S.; Weaver, S.C.; Makino, S.; LeDuc, J.W.; Menachery, V.D.; Shi, P.-Y. An Infectious cDNA Clone of SARS-CoV-2. Cell Host \& Microbe 2020, 27, 841-848.e843, https://doi.org/10.1016/j.chom.2020.04.004.

108.Chiem, K.; Morales Vasquez, D.; Park, J.G.; Platt, R.N.; Anderson, T.; Walter, M.R.; Kobie, J.J.; Ye, C.; Martinez-Sobrido, L. Generation and Characterization of recombinant SARS-CoV-2 expressing reporter genes. J. Virol. 2021, 95, e02209-20, https://doi.org/10.1128/jvi.02209-20.

109.Xie, X.; Muruato, A.E.; Zhang, X.; Lokugamage, K.G.; Fontes-Garfias, C.R.; Zou, J.; Liu, J.; Ren, P.; Balakrishnan, M.; Cihlar, T.; Tseng, C.-T.K.; Makino, S.; Menachery, V.D.; Bilello, J.P.; Shi, P.-Y. A nanoluciferase SARS-CoV-2 for rapid neutralization testing and screening of anti-infective drugs for COVID-19. Nature Communications 2020, 11, https://doi.org/10.1038/s41467-020-19055-7.

110.Silvas, J.A.; Vasquez, D.M.; Park, J.G.; Chiem, K.; Allué-Guardia, A.; Garcia-Vilanova, A.; Platt, R.N.; Miorin, L.; Kehrer, T.; Cupic, A.; Gonzalez-Reiche, A.S.; Bakel, H.V.; García-Sastre, A.; Anderson, T.; Torrelles, J.B.; Ye, C.; Martinez-Sobrido, L. Contribution of SARS-CoV-2 Accessory Proteins to Viral Pathogenicity in K18 Human ACE2 Transgenic Mice. J Virol 2021, 95, https://doi.org/10.1128/jvi.0040221.

111.Keep, S.; Oade, M.S.; Lidzbarski-Silvestre, F.; Bentley, K.; Stevenson-Leggett, P.; Freimanis, G.L.; Tennakoon, C.; Sanderson, N.; Hammond, J.A.; Jones, R.C.; Britton, P.; Bickerton, E. Multiple novel noncanonically transcribed sub-genomic mRNAs produced by avian coronavirus infectious bronchitis virus. The Journal of general virology 2020, 101, 1103-1118, https://doi.org/10.1099/jgv.0.001474.

112.Finkel, Y.; Mizrahi, O.; Nachshon, A.; Weingarten-Gabbay, S.; Morgenstern, D.; Yahalom-Ronen, Y.; Tamir, H.; Achdout, H.; Stein, D.; Israeli, O.; Beth-Din, A.; Melamed, S.; Weiss, S.; Israely, T.; Paran, N.; Schwartz, M.; Stern-Ginossar, N. The coding capacity of SARS-CoV-2. Nature 2021, 589, 125-130, https://doi.org/10.1038/s41586-020-2739-1.

113.Nelson, C.W.; Ardern, Z.; Goldberg, T.L.; Meng, C.; Kuo, C.H.; Ludwig, C.; Kolokotronis, S.O.; Wei, X. Dynamically evolving novel overlapping gene as a factor in the SARS-CoV-2 pandemic. Elife 2020, 9 , https://doi.org/10.1038/s41586-020-2739-1.

114.Peng, Q.; Fang, L.; Ding, Z.; Wang, D.; Peng, G.; Xiao, S. Rapid manipulation of the porcine epidemic diarrhea virus genome by CRISPR/Cas9 technology. J. Virol. Methods 2020, 276, https://doi.org/10.1016/j.jviromet.2019.113772. 